\title{
A study of nanostructured gold modified glassy carbon electrode for the determination of trace $\mathrm{Cr}(\mathrm{VI})$
}

\author{
BENZHI LIU, LIYUAN LU, MIN WANG and YANQIN ZI* \\ Department of Chemistry, Huaibei Coal Normal College, Huaibei, China 235000 \\ e-mail: ziyanqin@163.com
}

MS received 7 July 2008; revised 31 July 2008

\begin{abstract}
A nanostructured gold modified glassy carbon electrode ( $\left.\mathrm{Au}_{\mathrm{nano}} / \mathrm{GCE}\right)$ was employed for the determination of trace chromium(VI). To prepare $\mathrm{Au}_{\text {nano }} / \mathrm{GCE}$, the GCE was immersed into $\mathrm{KAuCl}_{4} \mathrm{Solu}^{-}$ tion and electrodeposition was conducted at the potential of $-0.4 \mathrm{~V}$ (vs $\mathrm{Ag} / \mathrm{AgCl}$ ) for $600 \mathrm{~s}$. Scanning electron microscopy measurements show that the electrochemically synthesized gold nanoparticles were deposited in aggregated form. Any undue effects caused by the presence of foreign ions in the solution were also analysed to ensure that common interference in the determination of chromium(VI) by square wave voltammetry, do not influence the electrochemical response of the latter element. The results show that this method allows for $\mathrm{Cr}(\mathrm{VI})$ determinations with a much lower detection limit $\left(0.01 \mu \mathrm{g} \mathrm{L}^{-1}\right)$ in the presence of excess of $\mathrm{Cr}$ (III) than the commonly used diethylenetriammine pentaacetic acid (DTPA) method. The method was applied to determine levels of chromium(VI) in tap water and sewage water.
\end{abstract}

Keywords. Nanostructured gold modified glassy carbon electrode; square wave voltammetry; $\mathrm{Cr}(\mathrm{VI})$.

\section{Introduction}

Chromium exists in natural samples in two main valence states as $\mathrm{Cr}(\mathrm{III})$ and $\mathrm{Cr}(\mathrm{VI})$. The two environmentally relevant valence states of chromium $\mathrm{Cr}$ (III) and $\mathrm{Cr}(\mathrm{VI})$ have a contrasting impact on environment and health. Trivalent chromium is relatively harmless and plays an essential role in biological processes, whereas hexavalent chromium is about 100-1000 times more toxic. ${ }^{1}$ Because of the different toxicities of these two valence states of chromium, it is necessary to determine $\mathrm{Cr}(\mathrm{VI})$ rather than the total concentration of $\mathrm{Cr}$ to estimate the toxicity of the sample. Many sensitive methods have been employed for the determination of chromium, such as atomic adsorption spectrophotometry, ${ }^{2,3}$ plasma mass spectrometry, ${ }^{4}$ spectrofluorimetry, ${ }^{5}$ chemiluminescence, ${ }^{6,7}$ spectrophotometry, ${ }^{8}$ but all these methods are time consuming and need high cost instrument, and also atomic absorption spectrometry (AAS) and inductively coupled plasma atomic emission spectrometry can only yield information on total Cr concentration. ${ }^{9}$ Therefore, electrochemical methods have been applied for the determination of chromium,

\footnotetext{
*For correspondence
}

which have shown numerous advantages including speed of analysis, good selectivity and sensitivity. ${ }^{10-13}$ Metal nanoparticles have shown superior or advantageous properties for a wide range of technological applications, ${ }^{14-17}$ and they provide three important functions for electroanalysis: improved mass transport, high effective surface area, and catalytic properties. ${ }^{18}$ Many methods were reported to synthesize metal nanoparticles including reduction with different reagents, ${ }^{19} \mathrm{UV}$ light or electron-beam irradiation ${ }^{20}$ and electrochemical methods. ${ }^{14-17}$ The latter provides an easy and rapid alternative for the preparation of metallic nanoparticle electrodes in a short span of time. In our work, nanostructured gold modified glassy carbon electrode was prepared by the latter method, and it was applied for reduction detection of $\mathrm{Cr}(\mathrm{VI})$ in trace level by adsorptive stripping voltammetric with the aim of an improved analytical performance (lower LOD and better reproducibility).

\section{Experimental}

\subsection{Apparatus}

Square wave voltammetry (SWV) experiments were conducted using Electrochemical Workstation LK2005 
(LANLIK Instruments company, Tainjin, China). The nanostructured gold modified glassy carbon electrode and gold electrode (disc diameter of $3 \mathrm{~mm}$ ) were used as working electrode with a $\mathrm{Ag} / \mathrm{AgCl}$ electrode (saturated $\mathrm{KCl}$ ) reference electrode, and a platinum wire auxiliary electrode. All $\mathrm{pH}$ measurements were made with a Model pHS-23 acidity meter (Shanghai Second Analytical Instruments, China). SEM images were obtained from an XL 30 ESEM FEG SEM (Philips, Netherlands) by this procedure. After the nanostructured gold modified GC electrode was prepared, the glassy carbon head was taken down and pasted onto the sample table of SEM, then SEM images were recorded.

\subsection{Reagents}

Standard solutions of $\mathrm{Cr}(\mathrm{VI})$ and $\mathrm{Cr}$ (III) $\left(1 \mathrm{gL}^{-1}\right)$, Potassium tetrachloroaurate(III)trihydrate $\left(\mathrm{KAuCl}_{4}\right)$, hydrogen chloride $(\mathrm{HCl})$, and all other compounds were purchased from Sinopharm Group Chemical Reagents Co. Ltd, and used without any further purification. A solution of $50 \mu \mathrm{M} \mathrm{KAuCl}{ }_{4}$ in $0 \cdot 1 \mathrm{M}$ $\mathrm{H}_{2} \mathrm{SO}_{4}$ was prepared for a solution stock to deposit gold at the GCE surface. All reagents used were analytical reagent-grade and double distilled water was used throughout.

\section{3 preparation of the $A u_{\text {nand }} / G C E$}

The glassy carbon electrode was polished with a water slurry of $0.5 \mathrm{~mm} \mathrm{Al} \mathrm{O}_{3}$, rinsed with ethanol and water and placed in an ultrasonic bath to remove any residual polishing material. The GCE was immersed into $\mathrm{KAuCl}_{4}$ solution and deposition was conducted at the potential of $-0.4 \mathrm{~V}(\mathrm{vs} \mathrm{Ag} / \mathrm{AgCl}$ ) for $600 \mathrm{~s}$.

\subsection{Measurement procedure}

SWVs were performed in $0 \cdot 10 \mathrm{M} \mathrm{HCl}$, if not stated otherwise. The $\mathrm{Cr}(\mathrm{VI})$ solutions were spiked into the cell and accumulation was carried out at $0.8 \mathrm{~V}$ with stirring. After a $15 \mathrm{~s}$ equilibration period, the voltammogram was recorded by applying a negativegoing square wave voltammetric potential scan from 0.6 to $0.0 \mathrm{~V}$ (with a step potential of $5 \mathrm{mV}$, amplitude of $25 \mathrm{mV}$ and frequency of $20 \mathrm{~Hz}$ ). A $35 \mathrm{~s}$ conditioning step at $+0 \cdot 1 \mathrm{~V}$ (with solution stirring) was used to remove the $\mathrm{Cr}(\mathrm{VI})$ residual, prior to the next cycle.

\section{Results and discussion}

\subsection{Deposition of gold at GCE surface}

It is known that the distribution of gold nanoparticle is important to perform good sensitivity of stripping voltammetry. The size, shape and size distribution of gold nanoparticles deposited at GCE during the process of nucleation followed by particle growth were affected by the concentration of gold salt, deposition time and deposition potential. ${ }^{21}$ To deposit nanosize gold particles, the $\mathrm{KAuCl}_{4}$ solution was made in low concentration. However, if the gold salt concentration was too low, the nucleation could not be formed. In this experiment, according to literature, ${ }^{21}$
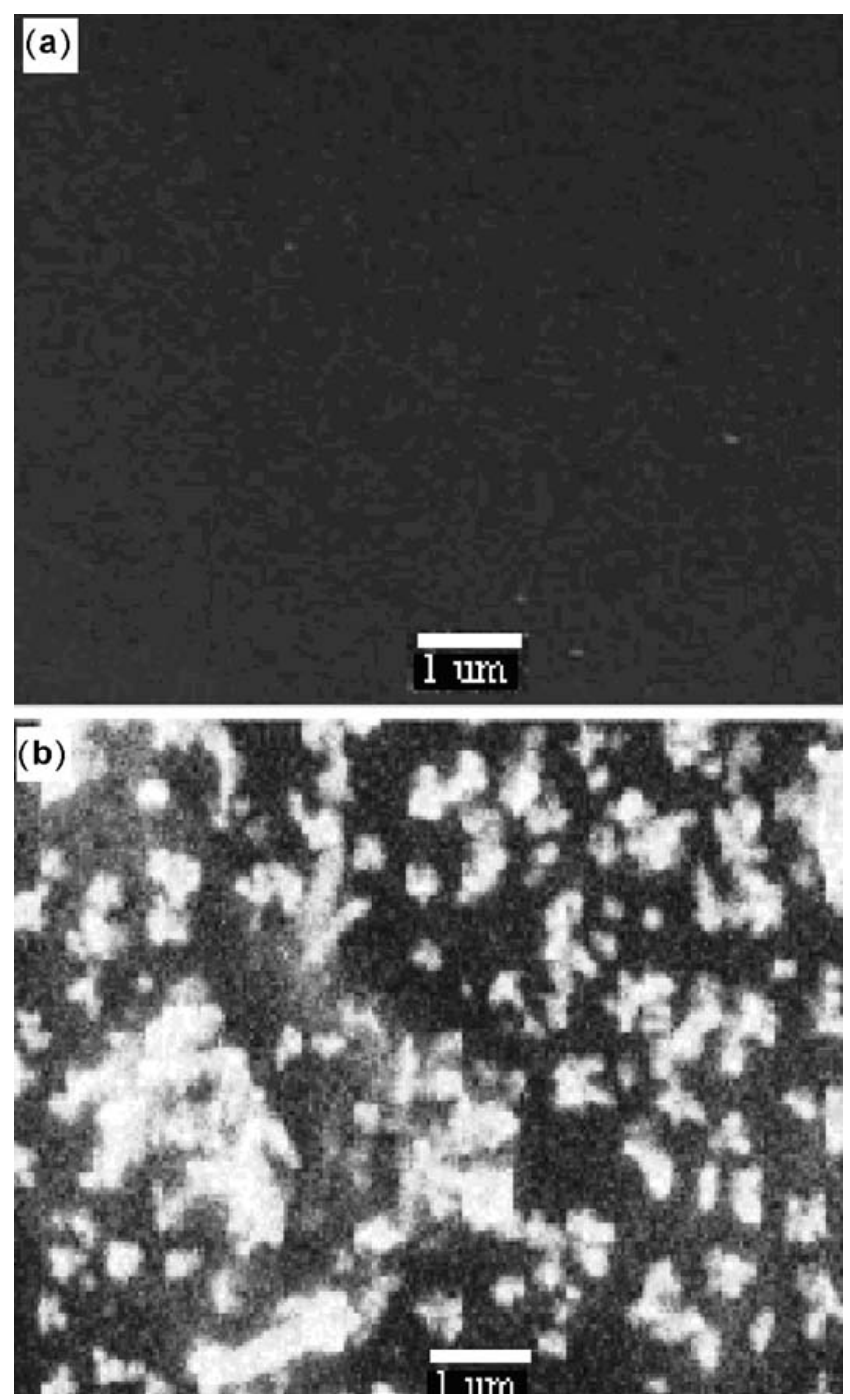

Figure 1. (a) SEM images of GCE and (b) gold nanoparticle-modified GCE. The GCE was immersed into $\mathrm{KAuCl}_{4}$ solution and electrodeposition was conducted at the potential of $-0.4 \mathrm{~V}$ ( $\mathrm{vs} \mathrm{Ag} / \mathrm{AgCl})$ for $600 \mathrm{~s}$. 
a concentration of $50 \mu \mathrm{M}$ gold salt and the deposition time of $600 \mathrm{~s}$ in $\mathrm{H}_{2} \mathrm{SO}_{4}$ were used for all experiments. Figure 1 shows the SEM image of gold nanoparticles at the GCE surface. As shown in figure 1 , gold nanoparticles can be clearly observed decorating the surface of GCE, and the particles were relatively uniform, while the formation of gold film or agglomerates was not observed.

\subsection{Electrochemical characterization of $A u_{\text {nand }}$ GCE}

The high effective surface area of $\mathrm{Au}_{\text {nano }} / \mathrm{GCE}$ was studied by performing an electrochemical characterization using cyclic voltammetry. Figure 2 shows steady CVs for (1) gold electrode and (2) $\mathrm{Au}_{\text {nano }} /$ GCE in $10 \mathrm{mM}\left[\mathrm{Fe}(\mathrm{CN})_{6}\right]^{3-/ 4}$ and $0.2 \mathrm{M} \mathrm{KCl}$ at $20 \mathrm{mV} / \mathrm{s}$. The well-defined oxidation and reduction peaks were observed at $+0 \cdot 16 \mathrm{~V}$ and $+0 \cdot 11 \mathrm{~V}$ due to the $\left[\mathrm{Fe}(\mathrm{CN})_{6}\right]^{3-14}$ redox couple in forward and reverse scans. The $\mathrm{Au}_{\text {nano }} / \mathrm{GCE}$ exhibited the high electroactive area according to the Randles-Sevcikequation: ${ }^{22}$

$$
I p=2.69 \times 10^{5} A D^{1 / 2} n^{3 / 2} v^{1 / 2} C .
$$

In this equation, $n$ is the number of electrons appearing in half-reaction for the redox couple, $v$ is the rate at which the potential is swept $(\mathrm{V} / \mathrm{s}), A$ is the electrode area $\left(\mathrm{cm}^{2}\right)$, The $\left[\mathrm{Fe}(\mathrm{CN})_{6}\right]^{3-/ 4}$ redox system used

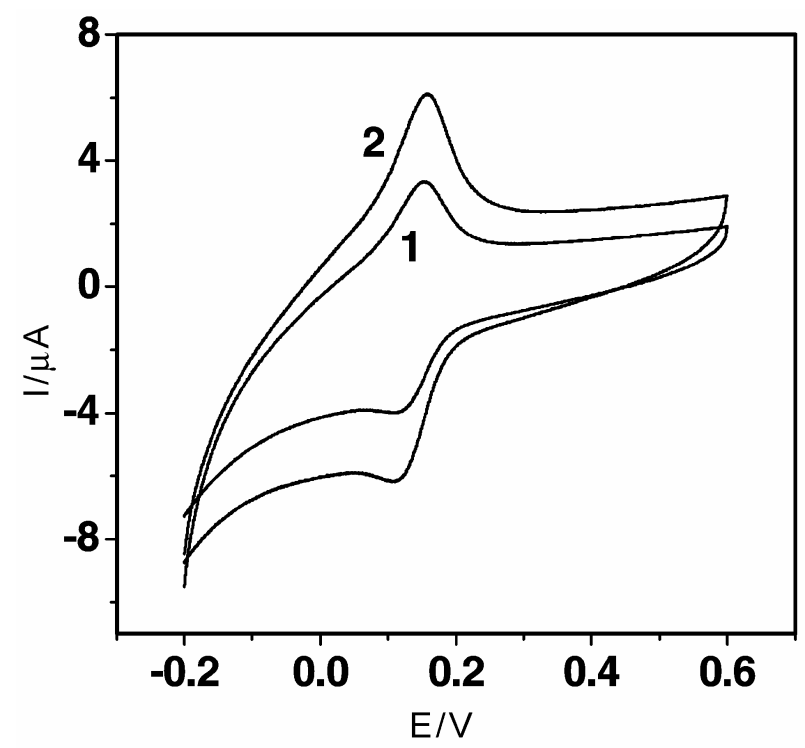

Figure 2. Cyclic voltammetries of (1) gold electrode and (2) $\mathrm{Au}_{\text {nano }} / \mathrm{GCE}$ in $10 \mathrm{mM}\left[\mathrm{Fe}(\mathrm{CN})_{6}\right]^{3-/ 4-}$ and $0.2 \mathrm{M}$ $\mathrm{KCl}$ at $20 \mathrm{mV} / \mathrm{s}$. in this work is one of the most extensively studied redox couples in electrochemistry ${ }^{23-27}$ and exhibits a heterogeneous one-electron transfer $(n=1)$. $C$ is equal to $10 \mathrm{mM}$, and the diffusion coefficient $(D)$ is $6.057 \times$ $10^{-6} \mathrm{~cm}^{2} / \mathrm{s}$. The value of the electroactive surface area for optimized $\mathrm{Au}_{\text {nano }} / \mathrm{GCE}$, and $\mathrm{Au}$ electrode were $0.41 \mathrm{~cm}^{2}$ and $0.19 \mathrm{~cm}^{2}$, respectively. A higher peak current value also illustrated an increase in the electroactive surface area for the $\mathrm{Au}_{\text {nano }} / \mathrm{GCE}$, mainly due to smaller size of $\mathrm{Au}$ nanoparticles distributed on the surface of GCE, which increased the large local rates of mass transport to the $\mathrm{Au}_{\mathrm{nan}} \mathrm{GCE}$.

\subsection{Electrochemical response of $\mathrm{Cr}(\mathrm{VI})$ on $A u_{\text {nand }} G C E$ and $A u$ electrode}

Figure 3 shows the SWVs for $2 \mu \mathrm{g} \mathrm{L}^{-1}$ of $\mathrm{Cr}$ (VI) determination with a $\mathrm{Au}_{\text {nano }} / \mathrm{GCE}(1)$ and $\mathrm{Au}$ electrode (2). a well-defined peak was observed at ca. $+0 \cdot 30 \mathrm{~V}$ in the cathode scan at Au electrode, which was due to the reduction of $\mathrm{Cr}(\mathrm{VI})$ to $\mathrm{Cr}(\mathrm{III})$, a well-defined peak takes $31 \%$ peak height enhancement over the $\mathrm{Au}$ electrode was also observed when $\mathrm{Au}_{\text {nano }} / \mathrm{GCE}$ was used. The voltammetric current remarkably enhanced, which may be attributed to larger effective surface area resulting from smaller size of $\mathrm{Au}$ nanoparticles supported on the surface of GCE. Therefore, measurement sensitivity could be improved by using $\mathrm{Au}_{\text {nano }} / \mathrm{GCE}$ for the determination of $\mathrm{Cr}$ (VI).

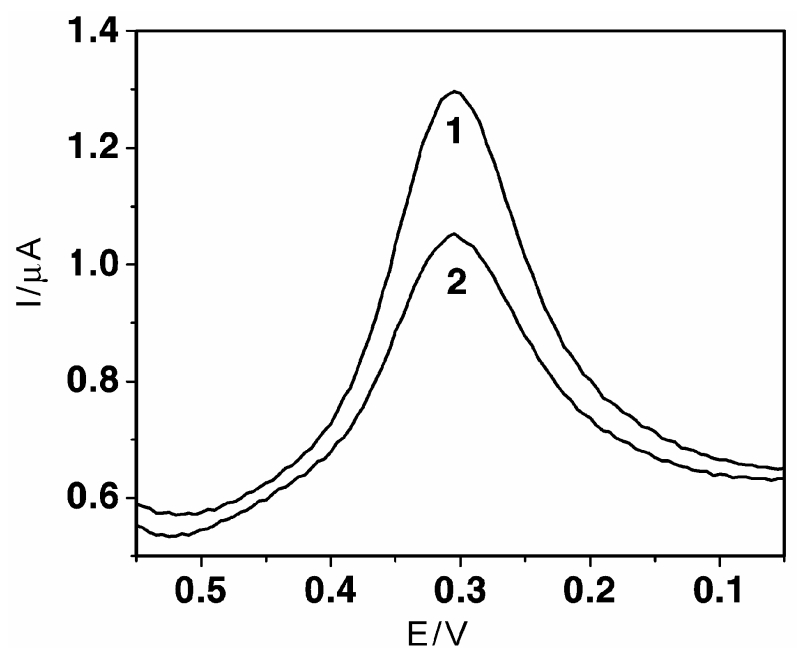

Figure 3. SWVs of $2 \mu \mathrm{g} \mathrm{L} \mathrm{L}^{-1} \mathrm{Cr}$ (VI) at $\mathrm{Au}_{\mathrm{nano}} / \mathrm{GCE}$ (1) and $\mathrm{Au}$ electrode (2) in $0.1 \mathrm{M} \mathrm{HCl}$. Accumulation for $80 \mathrm{~s}$ at $+0.8 \mathrm{~V}$, SWV detection conditions: step potential, $5 \mathrm{mV}$; amplitude, $25 \mathrm{mV}$; frequency, $20 \mathrm{~Hz}$. 


\section{$3.4 S W V$ s response of $C r(V I)$ in different acidity}

The reduction of $\mathrm{Cr}(\mathrm{VI})$ was examined in various solutions containing different concentrations of hydrochloric acid $(0 \cdot 1-0.001 \mathrm{M})$, which correspond to $\mathrm{pH}$ $1-3$, respectively. Figure 4 illustrates the SWVs response obtained in the solution containing $2 \mu \mathrm{g} \mathrm{L} \mathrm{L}^{-1}$ $\mathrm{Cr}(\mathrm{VI})$ in different acidity. It can be seen that the response of the $\mathrm{Au}_{\text {nano }} \mathrm{GCE}$ to $\mathrm{Cr}(\mathrm{VI})$ in $0.1 \mathrm{M} \mathrm{HCl}$ produced a well-defined peak, with a reduction peak at $+0.30 \mathrm{~V}$, the sharply decreased peak current was obtained in $0.01 \mathrm{M}$ and $0.001 \mathrm{M} \mathrm{HCl}$ in solution containing the same concentration of $\mathrm{Cr}(\mathrm{VI})$, with peak potential at $+0.26 \mathrm{~V}$ and $+0.22 \mathrm{~V}$, respectively. Lower magnitude of reduction current and negative peak potential indicating a proton-dependent process, this is in accordance with the reported work. ${ }^{21}$ Therefore, the response of the electrode recorded in $0.001 \mathrm{M} \mathrm{HCl}$ containing $2 \mu \mathrm{g} \mathrm{L}^{-1} \mathrm{Cr}(\mathrm{VI})$ produced very little analytical signal, possibly because of the low concentration of protons.

\subsection{Accumulation time}

The reduction potential of $\mathrm{Cr}(\mathrm{VI})$ to $\mathrm{Cr}(\mathrm{III})$ was at $+0.30 \mathrm{~V}$, in order to detect the whole $\mathrm{Cr}(\mathrm{VI})$ in solution, much higher potential was chosen to keep chromium at hexavalent states, the accumulation potential from $+0.40 \mathrm{~V}$ to $+1.0 \mathrm{~V}$ were investigated, results show that the highest peak current was occurred at accumulation potential of $+0 \cdot 8 \mathrm{~V}$, the peak current

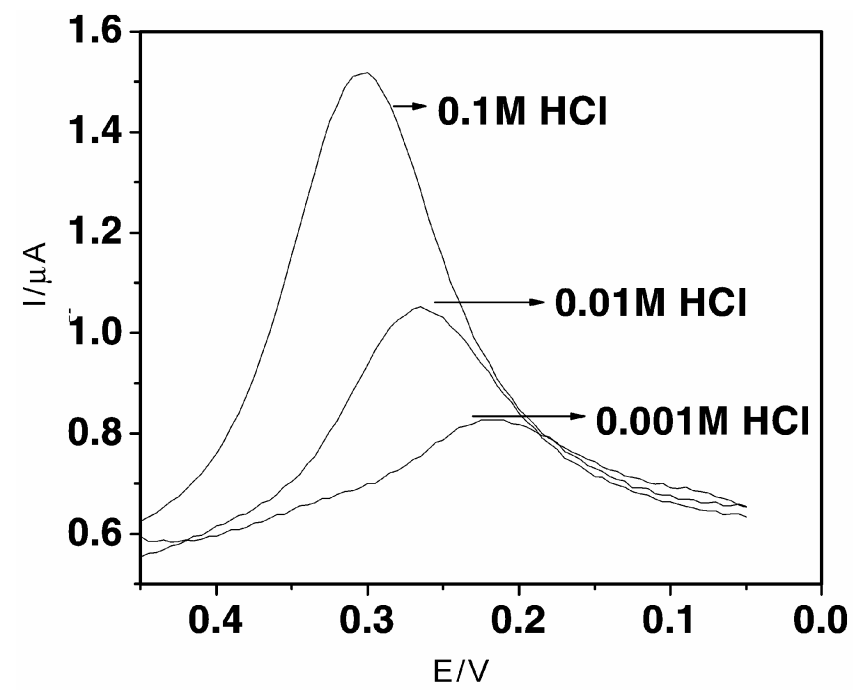

Figure 4. SWVs response obtained in the solution containing $2 \mu \mathrm{g} \mathrm{L}^{-1} \mathrm{Cr}(\mathrm{VI})$ in different acidity. Other conditions as in figure 3 . became unstable when the accumulation potential was higher than $+0.8 \mathrm{~V}$, therefore, accumulation potential of $+0.8 \mathrm{~V}$ was chosen in this experiment to keep chromium at hexavalent states. The accumulation time was further studied, figure 5 shows the SWVs in various accumulation time in solution containing $2 \mu \mathrm{g} \mathrm{L}^{-1} \mathrm{Cr}(\mathrm{VI})$. It can be seen that the response increases nearly linearly with the accumulation time up to $80 \mathrm{~s}$ accumulation, and levels off thereafter, which reflecting the electrode surface saturation. Therefore, an accumulation time of $80 \mathrm{~s}$ was utilized for all further measurements.

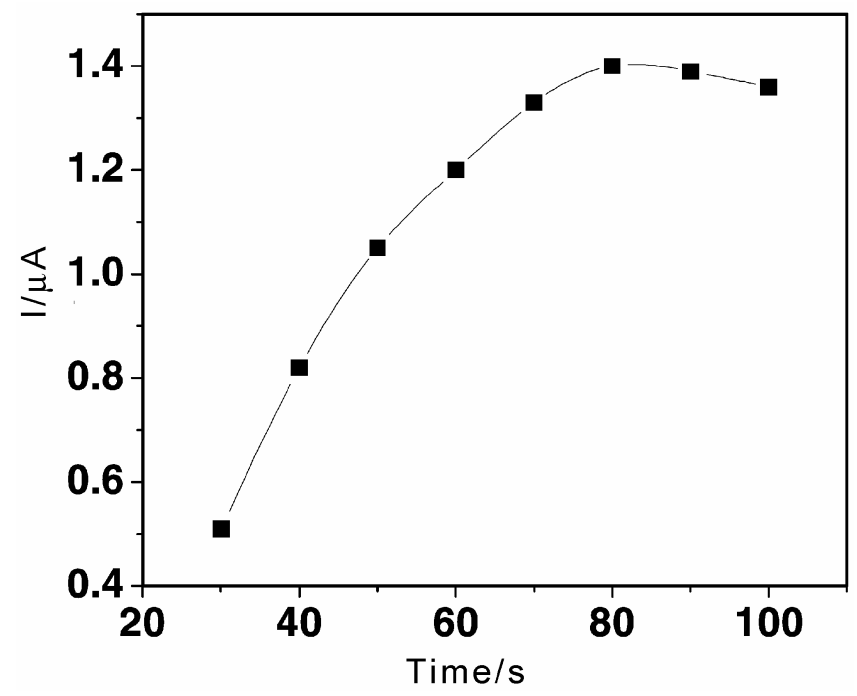

Figure 5. Effect of the accumulation time upon the response to $2 \mu \mathrm{g} \mathrm{L}^{-1} \mathrm{Cr}(\mathrm{VI})$. Other conditions as in figure 3 .

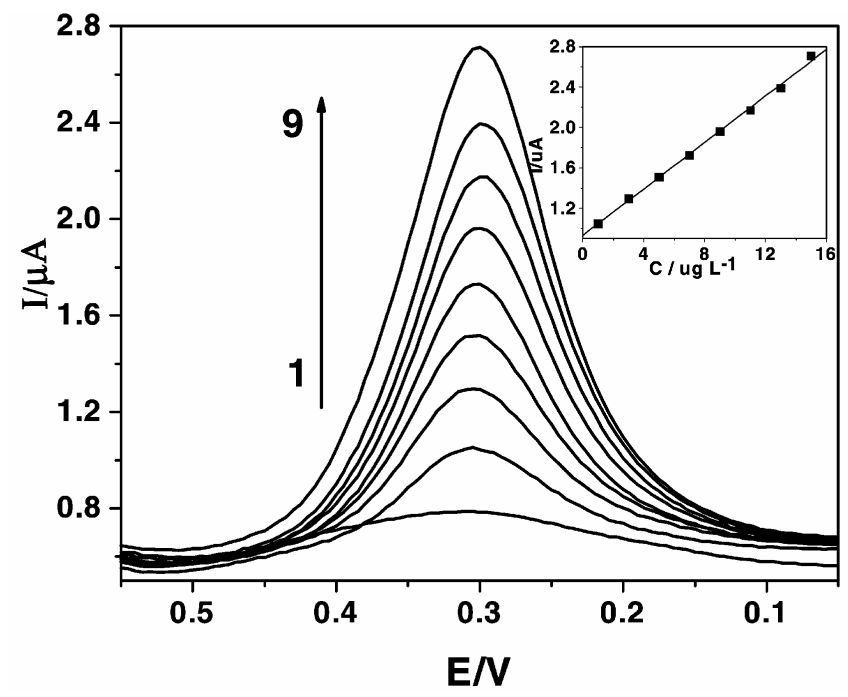

Figure 6. SWVs on $\mathrm{Au}_{\text {nano }} / \mathrm{GCE}$ in $0 \cdot 1 \mathrm{M} \mathrm{HCl}$ with different $\mathrm{Cr}(\mathrm{VI})$ concentration. (From 1 to $9: 0 ; 1 ; 3 ; 5 ; 7 ; 9$; $11 ; 13 ; 15 \mu \mathrm{g} \mathrm{L}^{-1}$, respectively. Inset is plot of current versus $\mathrm{Cr}(\mathrm{VI})$ concentration. Other conditions as in figure 3. 
Table 1. Determination of $\mathrm{Cr}(\mathrm{VI})$ in real samples.

\begin{tabular}{lcccccc}
\hline Samples & $\begin{array}{c}\text { This method } \\
(\mu \mathrm{g} / \mathrm{L})\end{array}$ & $\begin{array}{c}\text { DTPA method } \\
(\mu \mathrm{g} / \mathrm{L})\end{array}$ & $\begin{array}{c}\text { Added } \\
(\mu \mathrm{g} / \mathrm{L})\end{array}$ & $\begin{array}{c}\text { Found } \\
(\mu \mathrm{g} / \mathrm{L})\end{array}$ & $\begin{array}{c}\text { Recovery } \\
(\%)\end{array}$ & $\begin{array}{c}\mathrm{RSD}(\%) \\
(n=5)\end{array}$ \\
\hline Tap water & $0 \cdot 156$ & $0 \cdot 151$ & 0.2 & 0.339 & 91.5 & 5.7 \\
Sewage water & 4.98 & 5.02 & 5.0 & 9.79 & 96.2 & 4.6 \\
\hline
\end{tabular}

\subsection{Calibration graph}

Calibration curves for the determination of $\mathrm{Cr}(\mathrm{VI})$ on the $\mathrm{Au}_{\text {nano }} / \mathrm{GCE}$ was achieved by SWV under optimal conditions. The SWVs for different concentrations of $\mathrm{Cr}(\mathrm{VI})$ were illustrated in figure 6 . The resulting calibration plots is linear over the range from 0.13 to $45 \mu \mathrm{g} \mathrm{L}^{-1}$. The calibration curves and correlation coefficients are $y=0.932+0.115 x$ and $r=0.9988$ with an accumulation time of $80 \mathrm{~s}$, respectively. The limits of detection was $0.01 \mu \mathrm{g} \mathrm{L}^{-1}$ based on three times the standard deviation of the baseline. The reproducibility of the electrode asprepared was estimated from the response to each $2 \mu \mathrm{g} \mathrm{L}{ }^{-1}$ of $\mathrm{Cr}$ (VI) at 5 different electrodes by different operating time. This series yield a mean current response of $1.38 \mu \mathrm{A}$, corresponding to relative standard deviation (R.S.D.) of $6 \cdot 1 \%$. The results demonstrated that the $\mathrm{Au}_{\text {nano }} / \mathrm{GCE}$ could improve both the sensitivity and the reproducibility for the determination of Cr (VI) by SWV.

\subsection{Effect of foreign ions}

The influence of foreign ions on the determination of $\mathrm{Cr}(\mathrm{VI})$ was studied using fixed concentration of $\mathrm{Cr}(\mathrm{VI}), 2 \mu \mathrm{g} \mathrm{L}^{-1}$ and the accumulation time $80 \mathrm{~s}$. The addition of $\mathrm{Cr}$ (III) up to the concentration $200 \mu \mathrm{g} \mathrm{L}{ }^{-1}$ does not influence the current of the peak corresponding to $\mathrm{Cr}(\mathrm{VI})$. Further results showed that at least 500-fold amounts of $\mathrm{Zn}^{2+}, \mathrm{Pb}^{2+}, \mathrm{Fe}^{3+}, \mathrm{Ni}^{2+}$, $\mathrm{Mn}^{2+}, \mathrm{Cd}^{2+} ; 100$-fold amounts of $\mathrm{Cu}^{2+}, \mathrm{Co}^{2+}$, do not interfere. The addition of $\mathrm{MgSO}_{4}$ or $\mathrm{CaCl}_{2}$ at concentration $0.02 \mathrm{~mol} \mathrm{~L}^{-1}$ also does not influence the current of the peak. The influence of surface active substances was studied using Triton X-100. It was found that the addition of Triton X-100 at the concentration $0.1 \mathrm{mg} \mathrm{L}^{-1}$ caused little decrease of the peak. All these imply the possible direct application of this method in real samples which contain low concentration of surfactants.

\subsection{Analytical applications}

This method was applied to $\mathrm{Cr}(\mathrm{VI})$ determination in tap water (our laboratory) and sewage water sample (sewage water treatment station of Huaibei). The results are shown in table 1. Agreement between the results obtained by this method with that obtained by DTPA method ${ }^{28}$ for tap water and sewage water shows that this method can be used for determination of $\mathrm{Cr}(\mathrm{VI})$ in real samples. The results show that this method allows for $\mathrm{Cr}(\mathrm{VI})$ determinations with a much lower detection limit in the presence of excess of $\mathrm{Cr}$ (III) than the commonly used DTPA method. ${ }^{28}$

\section{Conclusion}

In this paper, a simple method for the fabrication of nanostructured gold modified glassy carbon electrode was presented. It has been shown that, after proper optimization of the experimental conditions, the electrode prepared was suitable for the determination of $\mathrm{Cr}(\mathrm{VI})$ with high sensitivity and good reproducibility. The method developed was applied to real samples which gave satisfactory results.

\section{References}

1. Cespon-Romero R M, Yebra-Biurrun M C and Bermejo-Barrera M P 1996 Anal. Chim. Acta 32737

2. Eiras S D P, Custodio U M and Pavanim L A 2003 Talanta $\mathbf{5 9} 621$

3. Bag H, Turker A R, Lale M and Tunceli A 2000 Talanta $\mathbf{5 1} 895$

4. Hirata S, Honda K, Shikino O, Maekawa N and Aihara M 2000 Spectrochim. Acta B55 1089

5. Tang B, Yue T, Wu J, Dong Y, Ding Y and Wang H 2004 Talanta 64955

6. Gammelgaard B, Liao Y P and Jons O 1997 Anal. Chim. Acta 354107

7. Muto K, Ohno K, Lin J M and Yamada M 2003 Jpn. J. Iron Steel 8968

8. Kaneko M, Kurihara M, Nakano S and Kawashima T 2002 Anal. Chim. Acta 474167

9. Yalc S and Apak R 2004 Anal. Chim. Acta 50525 
10. Dominguez O and Arcos M J 2000 Electroanalysis 12449

11. Torrance K and Gatford C 1987 Talanta 34939

12. Hua C, Sagar K M, McLaughlin K, Jorge M, Meaney M P and Smyth M R 1991 Analyst 116117

13. Morais S, Carvalho S G and Sousa J P 1998 J. Trace Elem. Med. Biol. 12101

14. Majid E, Hrapovic S, Liu Y, Male K B and Luong J H T 2006 Anal. Chem. 78762

15. Dai X, Nekrassova O, Hyde M E and Compton R G 2004 Anal. Chem. 765924

16. El-Deab M S, Kajima T O and Ohsaka T $2003 \mathrm{~J}$. Electrochem. Soc. 150 A851

17. Welch C M, Banks CE, Simm A O and Compton R G 2005 Anal. Bional. Chem. 38212

18. Dai X, Wildgoose G G, Salter C, Crossley A and Compton R G 2006 Anal. Chem. 786102

19. Sun L, Zhang Z and Dang H 2003 Mater. Lett. 57 3874
20. Fukushima M, Yanagi H, Haayashi S, Suganuma N and Taniguchi Y 2003 Thin Solid Films 39438

21. Yamada D, Ivandini T A and Einaga Y 2008 J. Electroanal. Chem. 615145

22. Bard A J and Faulkner L R 2000 Electrochemical methods-fundamentals and applications (New York: John Wiley and Sons)

23. Miller C, Cuendet P and Cratzel M 1991 J. Phys. Chem. 9587

24. Zhang S X, Fu Y Q and Sun C Q 2003 Electroanalysis $\mathbf{1 5} 739$

25. Melissa B R, Darren C C and Alan M B 2000 Anal. Chem. 723486

26. Diao P and Tong R T 2000 Chin. Chem. Lett. 11 1085

27. Sundfors F, Bobacka J, Ivaska A and Lewenstam A 2002 Electrochim. Acta 472245

28. Boussemart $M$, van den Berg C M G and Ghaddaf $M$ 1992 Anal. Chim. Acta 262103 